The Position of Geography

Author(s): C. F. Close

Source: The Geographical Journal, Vol. 38, No. 4 (Oct., 1911), pp. 404-413

Published by: geographicalj

Stable URL: http://www.jstor.org/stable/1778545

Accessed: 18-06-2016 08:38 UTC

Your use of the JSTOR archive indicates your acceptance of the Terms \& Conditions of Use, available at

http://about.jstor.org/terms

JSTOR is a not-for-profit service that helps scholars, researchers, and students discover, use, and build upon a wide range of content in a trusted digital archive. We use information technology and tools to increase productivity and facilitate new forms of scholarship. For more information about JSTOR, please contact support@jstor.org.

The Royal Geographical Society (with the Institute of British Geographers), Wiley are collaborating with JSTOR to digitize, preserve and extend access to The Geographical Journal 
Dakotas, Nebraska, Kansas, Oklahoma, and Texas, 75,548,641 of the total population dwelt east of that line in 1910 , and only $16,423,625$ west of it. Nevertheless the comparatively faint and partial evidence of the westward movement of population appearing in the map for 1890-1900 is replaced by strong and general evidence in that for the past decade.

(To be continued.)

\section{THE POSITION OF GEOGRAPHY.*}

\section{By Colonel C. F. CLOSE, C.M.G., R.E.}

I PROPOSE to devote the first part of this address to an examination of the purpose and position of geography, with special reference to its relations with other subjects. It will not be possible entirely to avoid controversial matters; but, if some of the questions touched on are controversial, this only means that these questions have a certain importance. I shall try to describe the facts of the case impartially.

In the second part I shall try to indicate briefly what the Government, as represented by the great Departments of State, is doing for geography.

\section{PART I.-The Position of Geography with reference to other Subjects.}

It is no secret that the geographical world is not unanimous about the meaning and object of geography. The definitions suggested by such writers as Mr. Chisholm, Prof. Davis, Prof. Herbertson, Mr. Mackinder, or Dr. Mill, are not in agreement. From time to time an attempt is made to formulate some statement which shall not commit the subscribers to anything very definite. But differences of opinion on the subject persist.

There are, of course, a great many ways of approaching the question. Let us, for example, examine the proceedings of such representative bodies as the British Association and the Royal Geographical Society, and of such assemblies as the International Geographical Congresses, and let us see if we can find out what is, as a fact, the scope of the subject as dealt with by these bodies. They are institutions which work in the full light of day, and they are too large to be dominated for any length of time by individuals. If we can find any working principle, any common term, amongst these societies, we shall have gone some way towards arriving at a solution of the problem.

A simple method of investigation is to discuss the character of the publications of these societies and of the lectures delivered before them. And I feel that I cannot do better than devote most of this brief analysis to the Royal Geographical Society and its admirably edited Journal. Here we are on safe ground. If an inhabitant of another planet wished to know what we understand by astronomy we could confidently refer him to the Monthly Notices of the Royal Astronomical Society. If he were curious about the condition of geology, we should give him the volumes of the Geological Society. And, if he were so rash as to ask what are the objects of the modern mathematician, we should hand him the papers published by the London Mathematical Society. The Geographical Journal occupies no lower a position with reference to

* Presidential Address to the Geographical Section of the British Association at Portsmouth, August 31, 1911. 
Geography than do the other journals mentioned with reference to the sciences with which they deal.

In analysing the contributions to the Royal Geographical Society it is important to start with an honest classification. In the endeavour to be impartial I have chosen the classification which was adopted for the last International Geographical Congress, i.e. that held at Geneva in 1908. This Congress was divided into fourteen sections. It will serve to clear the ground if we deal first with sections 12, 13, and 14; these are the Teaching of Geography, Historical Geography (which was mainly concerned with the history of travel and exploration and Rules and Nomenclature). For the purpose of discovering what geography is these three sections will not be of any assistance, Every subject has its educational side, its history, and its rules and nomenclature. The subject proper was, therefore, divided into eleven sections. The eleven sections are the following :-

1. Mathematical and Cartographical Geography.

2. General Physical Geography.

3. Vulcanology and Seismology.

4. Glaciers.

5. Hydrography (Potamography and Limnology).

6. Oceanography.

7. Meteorology and Climatology; Terrestrial Magnetism.

8. Biological Geography.

9. Anthropology and Ethnography.

10. Economic and Social Geography.

11. Explorations.

Before applying this classification to the work of the Geographical Society, I wish to call attention to the extremely frank way in which vulcanology, seismology, meteorology, climatology, terrestrial magnetism, anthropology, and ethnography are included in geography. The list, in fact, covers ground occupied by several sections of the British Association.

I have investigated the work of the Geographical Society for the five com. plete years 1906 to 1910 . The original contributions to the Geographical Journal have been examined for that period, omitting from consideration contributions on the subjects of teaching, the history of exploration, and rules and nomenclature.

There are altogether 296 original papers which come under one or another of the eleven headings given above. Of these papers, 171, or 57 per cent., deal with Explorations and Travels. There is a great drop to the next largest section, General Physical Geography, which accounts for thirty papers, or about 10 per cent. Adhering to the order of the Geneva Congress, the complete list is as follows :-

\section{Original Contributions to the Proceedings of the Royal Geographical Society during} the five years 1906 to 1910.

Subject

1. Mathematical and Cartographical Geography ...

$\begin{array}{lllllll}\cdots & \ldots & \ldots & \ldots & \ldots & \ldots & 10\end{array}$

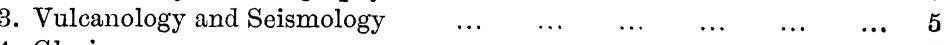



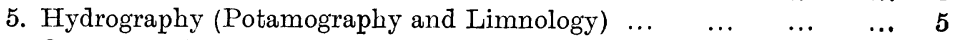

$\begin{array}{lllllllllll}\text { Oceanography } \ldots & \ldots & \ldots & \ldots & \ldots & \ldots & \ldots & \ldots & \ldots & 3\end{array}$

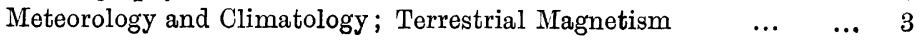




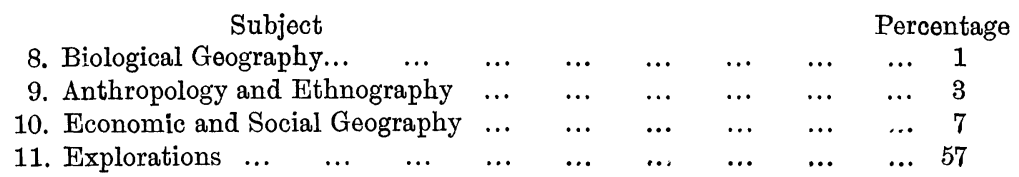

The main conclusion is obvious enough. For the principal geographical society in the world, geography is still mainly an affair of explorations and surveys; if to this item we add cartography we account for 60 per cent. of the activities of the Society.

There is another important deduction which is natural and unforced: the papers on vulcanology and seismology and on glaciers could have been read with perfect appropriateness before the Geological Society; those on meteorology and climatology before the Meteorological Society; and those on anthropology and ethnography before the Anthropological Society. To make quite sure of this point I will cite a few titles of the papers read: "The great Tarawera Volcanic Rift," by J. M. Bell ; "Recent Earthquakes," by R. D. Oldham; "Glacial History of Western Europe," by Prof. T. G. Bonney ; "Climatic Features of the Pleistocene Ice-Age," by Prof. A. Penck; "Rainfall of British East Africa," by G. B. Williams ; "Geographical Distribution of Rainfall in the British Isles," by Dr. H. R. Mill; "Geographical Conditions affecting Population in the East Mediterranean Lands," by D. G. Hogarth ; “Tribes of North-Western Se-Chuan," by W. N. Fergusson.

This little list of typical subjects indicates clearly that there is a large group of contributions which would have found an appropriate home in the journals of the Geological, Meteorological, and Anthropological Societies; there is a possible corollary that, since men who make a life study of these subjects are best capable of dealing with them, the authors of the above type of paper who submit their work to the Geographical Society, in so doing appeal rather to the public at large than to men of their own special sciences.

We may, therefore, sum up the results of this brief investigation into the work of the Royal Geographical Society by saying that 60 per cent. of it is concerned with exploration and mapping, and that some of the remainder could be dealt with appropriately by the learned societies concerned, but that the Geographical Society serves as a popularizing medium. It also serves a useful purpose as a common meeting-ground for vulcanologists, seismologists, oceanographers, meteorologists, climatologists, anthropologists, and ethnographers.

Another line of investigation may be profitably pursued. Who are, by common consent, the leading geographers of the world? No doubt the explorers come first in popular estimation, such men (omitting British names) as Peary, Charcot, and Sven Hedin. Then after this type would come the men of learning who stand out in any International Congress. These men stand out because they have, by their own exertions, increased the sum of human knowledge. Omitting for the moment the consideration of exploration and mapping, we find that in an international congress a large number of the most celebrated geographers are eminent as geologists. In such a gathering we can also pick out those who have advanced the sciences of meteorology or anthropology. Now let us suppose the position reversed. Let the functions of geology be supposed to be somewhat in dispute and those of geography perfectly definite, and further let us suppose that at an international meeting of geologists a large proportion of the men of real distinction were geographers. We may in this way get an idea of what geography looks like from the outside.

I think that at this point we may explain, in a preliminary way, the work 
of the geographical societies, after the fashion of the 'Child's Guide to Knowledge':-

Question: What is geography?

Answer: There is no generally accepted definition of geography.

Question: Can we not form some idea of the scope of the subject by considering the work of the Royal Geographical Society ?

Answer: Yes ; 60 per cent. of this work deals with explorations, surveys, and mapping, and of the rest a considerable portion consists of matter which could be discussed appropriately before the Geological, Meteorological, and Anthropological Societies.

Question: What, then, leaving maps out of consideration, are the useful functions of a geographical society?

Answer: A geographical society serves to popularize the work of men who labour in certain fields of science, and such a society forms a very convenient meeting-ground for them.

Question: What is a geographer?

Answer: The term "geographer" is sometimes applied to explorers; sometimes to men who compile books derived mainly from the labours of surveyors, geodesists, geologists, climatologists, ethnographers, and others; sometimes to those who compile distributional maps.

Question: Can a geographer who has not made a special study of one or more of such subjects as geodesy, surveying, cartography, geology, climatology, or ethnography, hope to advance human knowledge?

Answer: He can do much to popularize these subjects, but he cannot hope to do original work.

Another way of attempting to ascertain the meaning and object of geography is to study the character of the instruction given in the universities, and we may suppose that this can be fairly judged by the contents of standard textbooks. Let us take, for example, the "Traité de Géographie Physique" of M. E. de Martonne, formerly Professor of Geography at the University of Lyons, now Professor at the Sorbonne. The work in question was published in 1909, and is divided into four main sections-Climate, Hydrography, Terrestrial Relief, and Biogeography.

The first sentence of the book is "What is Geography?" Twenty-four pages are devoted to discussing this question, which the writer, with all his skill and learning, finds it difficult to answer definitely and convincingly. One receives the impression of the dexterous handling of a difficult question, and of a generally defensive attitude. In this book geography is said to depend on three principles-the principle of extension, the principle of co-ordination, and the principle of causality. As an illustration of the meaning of the principle of extension, we are told that " the botanist who studies the organs of a plant, its conditions of life, its position in classification, is not doing geographical work ; but if he seeks to determine its area of extension, il fait de la géographie botanique." I believe that we have here reached a critical point. The claim is, that when in the prosecution of a botanical study, a map is used to show the distribution of a plant, the use of such a map converts the study into a branch of geography. Well, it is a question of definition and convention, which cannot, I imagine, be settled except by the general agreement of all the sciences. We have to make up our minds whether a man who constructs a distributional map is doing "geography." One thing, I suppose, is not doubtful,-when the map is made it will be better interpreted by a botanist than by a person ignorant of botany. In the same way the discussion of an ordinary geological map is best undetaken 
by a geologist, and so on. It would appear that geography, in the sense mentioned, is not so much a subject as a method of research.

It will be convenient here to say a few words about the relations between societies and schools of geography and those two important subjects geodesy and geology. Curiously enough, there is not, and has never been, in the United Kingdom a society or body specially charged with the study of geodesy. Geodesy, in fact, has no regular home in these islands. But the Royal Geographical Society has done a good deal in the past few years to stimulate an interest in the subject, thereby fulfilling what I believe to be one of the Society's most useful functions-that of popularization.

If, however, an authoritative opinion were required on any geodetic question, where could it be obtained? Well, I suppose there is no doubt that the headquarters of this branch of learning is the International Geodetic Association, but the scientific work itself is being largely carried out at the Geodetic Institute at Potsdam, by the Survey of India, by the Geodetic Section of the Service Géographique, by the U.S. Coast and Geodetic Survey, and by similar bodies. Geodesy, especially in its later developments, is a definitely scientific subject which demands much study and application. It is but slightly touched upon by the schools of geography. Perhaps I may here point out that geodesy is by no means mainly concerned with the shape of the spheroid. The chief problems are now those of isostasy and local attraction generally, the real shape of the sea-surface, the continuity of the crust of the Earth and changes of density therein.

The position in which geography finds itself with regard to geology can be clearly seen if reference is made to the new edition of the 'Encyclopædia Britannica.' In the eleventh volume of this work are two important articles"Geography," by Dr. H. R. Mill, and "Geology," by Sir Archibald Geikie. In the aricice on "Geography" we find a description of geomorphology as that part of geography which deals with terrestrial relief, and a remark is made that "opinion still differs as to the extent to which the geographer's work should overlap that of the geologist." In this article, however, most of the authorities quoted are geologists, and the author remarks that "the geographers who have hitherto given most attention to the forms of the land have been trained as geologists."

Turning to the article on "Geology," we find an important section on "Physiographical Geology," which is described as dealing with the investigation of "the origin and history of the present topographical features of the land." Now, this is the exact field claimed for geomorphology. It has been observed by others, notably by Prof. de Martonne, thàt the interpretation of topographic forms has been most successfully undertaken by geologists, and he gives as an instance of this the good work done by the United States Geological Survey.

I do not know whether any geographer untrained as a geologist has contributed anything of value to geomorphology.

Another test which may be applied is the following: Let us imagine geography to be non-existent, and note what the effect would be. Suppose there were no such things as Government geographical services, or sohools of geography at the Universities, or geographical societies. The first and most obvious result would be that most, if not all, of our apparatus of exploration and mapping would have disappeared. But as we are all in agreement as to the necessity of this branch of human effort, let us restore this to existence and examine the effect of the disappearance of the rest.

So far as concerns geodesy, we should still possess the International Geodetic 
Association, the Geodetic Institute at Potsdam, and the United States Geodetic Survey, and similar bodies. But we should have lost the means of popularizing geodesy in the proceedings of geographical societies; and, as there would be now no geographical text-books, elementary geodesy would not find itself between the same covers as climatology and geomorphology.

As regards geomorphology, or physiographical geology, not very much difference would be noted. The geologists would still pursue this important subject; but here, again, their writings would perhaps appeal to a more expert and less popular audience-alihough it is not to be forgotten that many admirable introductions to the subject have been written by geologists.

Much the same might be said about meteorology and climatology. There would be text-books devoted to these studies, but there might be a diminution of popular interest.

Such names as phytogeography would disappear, but the study of botany (if we permit it the use of distributional maps) would not be affected. The loss to knowledge would be mainly that of getting to a certain extent out of touch with the public. The constitutions of the various learned bodies would remain the same and so would their functions. The constitution of the Royal Society, which has never recognized geography as a subject, would be totally unaffected.

If we thus study the relations between geography and other subjects we are almost bound to arrive at the conclusion that geography is not a unit of science in the sense in which geology, astronomy, or chemistry are units. If we inquire into the current teaching of geography, and examine modern text-books, we find that most of the matter is derived directly from the workers in other fields of study. And if we inquire into the products of geographical societies, it becomes evident that one of the most important functions fulfilled by these useful bodies is to popularize the work of geodesists, geologists, climatologists, and others, and to provide a common meeting-ground for them. If geography had been able to include geology and other sciences which deal with Earth-knowledge, it would then, indeed, have been a master science. But things have worked out differently.

I shall very probably be told that, in laying some stress on the above. mentioned aspects of the subject, I have forgotten that the main purpose of geography is the study of the Earth, as the home of man, or the study of man as affected by his environment, and that, however necessary it may be to begin with a foundation of geodesy, geology, and climatology, we must have as our main structure the investigation of the effect of place conditions on the races of man, on human history and human industry, on economics, and politics.

It is obviously and abundantly true that no student of history, economics, or politics can disregard the effect of geographical environment. But it is not, as a fact, disregarded by writers on these subjects. The question is, to a large extent, whether we should annex these portions of their studies, group them and label them "Geography." Our right to do this will depend on the value of our own original investigations. We have the right to use the results obtained by others, provided that we add something valuable of our own.

Before this human aspect of geography-or, for that matter, any other aspect of the subject-is recognized by the world of science as an independent, indispensable, and definite branch of knowledge, it must prove its independence and value by original, definite, and, if possible, quantitative research. 


\section{PART II.-Geography and the Government Departments.}

Whatever definition of geography is accepted, we are all in agreement that the map is the essential foundation of the subject. I propose now to indicate very briefly how the British Government, as represented by the great departments of State, is, in this respect, assisting the cause of geography. The departments which are interested in maps and surveys are the following :-The Admiralty, the War Office, the Colonial Office, the India Office, the Board of Agriculture, and the Foreign Office.

The immense services rendered, not only to this country, but to the whole world, by the Hydrographic Department of the Admiralty, are known to all. But it would be somewhat rash of a soldier to talk about hydrographic surveys, so I will confine my remarks to surveys on land.

First, it should be remarked that the British Government as a whole has for many years shown its interest in geography, and has recognized the good work done by the Royal Geographical Society by contributing an annual sum of $£ 500$ towards the funds of the Society. Next it should be noted that from time to time British Governments have contributed large sums of money towards Arctic and Antarctic exploration. The most recent examples of this very practical form of encouragement will be remembered by all; I mean the Government expenditure on Scott's first Antarctic Expedition, and the handsome sum contributed towards the cost of Shackleton's great journey.

Turning now to the War Office, the first matter to which I would call atten. tion is that nearly all the accurate topographical surveys of the Empire have been started by soldiers. This applies to the United Kingdom, Canada, Australia, South Africa, Tropical Africa, and last, but greatest of all, India. The accounts of the struggles of soldiers at the end of the eighteenth century to obtain sanction for what is now known as the Ordnance Survey form very interesting reading. In fact, all over the world it was military requirements which produced the topographical map ; and it is still the War Offices of the world which control the execution of almost all geographically important surveys. During the last few years the largest block of work undertaken by the War Office has been the accurate survey of the Orange Free State, which has an area of about 52,000 square miles-nearly the size of England-and an adjacent reconnaissance survey in the Cape of Good Hope covering an area of 100,000 square miles. There has been some inevitable delay (due to causes which need not be gone into now) in the publication of the sheets of this survey, but the work is being pushed on. The survey of the Orange Free State is fully comparable with the admirable surveys carried out by the French Service Géographique de l'Armée in Algeria and Tunis. Some work has also been done in the Transvaal. Other surveys carried out in recent years under the direct control of the War Office are those of Mauritius, St. Helena, a portion of Sierra Leone, Malta, and Hong Kong. The most notable work which is now being carried out in the SelfGoverning Dominions is the Militia Department Survey of Canada with which excellent progress has been made.

The total area of the Crown colonies and protectorates, under the rule of the Colonial Office, amounts to about 2,000,000 square miles. British African Protectorates form a large portion of this total, and I will indicate briefly what is being done to survey these tropical protectorates. From the geographical point of view, the brightest regions are East Africa, Uganda, and Southern Nigeria. In East Africa topographical surveys of the highlands and coast belt are being pushed on by military parties as part of the local survey department, 
The area of exact work done amounts now to some 30,000 square miles. In Uganda a military party has recently completed a large block of country, and in this protectorate thoroughly reliable maps of 32,000 square miles are now available. In Southern Nigeria a completely reorganized survey department is tackling in a thoroughly systematic fashion the difficult task of mapping a forest-clad country. We shall shortly see the results.

For the information of those who have not travelled in Tropical Africa it should be remarked that surveying in such countries is attended by every sort of difficulty and discomfort, and too often by illness and serious discouragement. It is one thing to sit at home in a comfortable office and plan a scheme of survey, and quite another thing to carry it out on the spot. We do not, I am convinced, give enough honour and credit to those who actually get the work done in such trying circumstances. Honest accurate survey work in the tropics puts a much greater strain on a man than exploratory sketching. To picture what the conditions are, imagine that you are to make a half-inch survey of the south of England; cover the whole country with dense forest; put mangrove swamps up all the estuaries; raise the temperature to that of a hot-house; introduce all manner of insects; fill the country with malaria, yellow fever, blackwater fever, and sleeping sickness; let some of your staff be sick; then have a fight with the local treasury as to some necessary payment, and be as cheerful as you can. That is one side of the medal. On the other side there is the abiding interest which the surveyor feels in the country, the natives, and the work; the sense of duty done; and the satisfaction of opening up and mapping for the first time a portion of this world's surface.

There is no time to mention other surveys in Africa, and I will pass on to a very interesting part of the world, the Federated Malay States. In this prosperous country much excellent geographical work is being done by the combined survey department which was established under a Surveyor-General in the year 1907. The department is in good hands, and the commencement of a regular topographical series is being undertaken.

I wish it were possible to prophesy smooth things about Ceylon. From our special point of view the situation leaves much to be desired. There is not yet published a single topographical map, and the topographical surveys are progressing at a rate which, under favourable conditions, may result in the maps being completed in the year 1970.

In closing this inadequate review of the principal surveys which are being undertaken in the Crown Colonies and Protectorates, I should mention that the co-ordinating factor is the Colonial Survey Committee, which every year publishes a report which is presented to Parliament.

The India Office is, of course, concerned with that great department the Survey of India. The Indian Empire has an area of about $1,800,000$ square miles, and as, under the arrangements approved in 1908, the standard scale of survey is to be 1 inch to 1 mile, the area of paper to be covered will be $1,800,000$ square inches. Actually this is divided into about 6700 sheets. The Survey of India has always been famous for its geodetic work and for its frontier surveys and methods. Its weak point used to be its map reproduction. This has been greatly improved. But personally I feel that if, for most military and popular purposes, a half-inch map is found suitable for England, as is undoubtedly the case, there is no reason why a half-inch map should not also be suitable for India. It is mainly a question of putting more information on the published map, and of engraving it and using finer means of reproduction. If this smaller scale were adopted, all the information now presented could be shown, and the 
number of the sheets would be reduced from 6700 to 1675 , a saving of 5000 sheets. It is difficult to avoid the feeling that the Survey of India is overweighted with the present scheme. The scheme has, however, many merits. It will be impossible to carry it out unless the department is kept at full strength.

The Board of Agriculture is the department which is charged with the administration of the Ordnance Survey. The Ordnance Survey spends some $£ 200,000$ a year, and for that sum it furnishes the inhabitants of the United Kingdom with what are, without doubt, the finest and most complete series of large-scale maps which any country possesses. There is nothing in any important country (such as France, Germany, Italy, Russia, or the United States) to compare with our complete and uniform series of sheets on the scale of $1: 2500$. These sheets are sold at a nominal price, and are in effect a free gift to landowners, agents, and all who deal with real property. They are also, of course, invaluable to county and borough engineers and surveyors. They really are a national asset which is not half enough appreciated. The whole conception of these large-scale plans has stood the test of time, and is greatly to the honour of a former generation of officers.

Much might be said about the small-scale maps of the Ordnance Survey, which are now published in a very convenient form. As mentioned below, the latest small-scale Ordnance map is the new international map on the million scale. Some sheets of this map will shortly be published.

The Foreign Office is concerned with the surveys of the Anglo-Egyptian Sudan, which are at present mainly of an explanatory character. The taking over of the province of Lado has recently thrown fresh work on the Sudan Survey Department. The Foreign Office, which administers Zanzibar, has recently given orders for the survey of the island of Pemba, a dependency of Zanzibar, and this is being carried out by a small military party.

But the greatest service to geography rendered by the Foreign Office in recent years was the encouragement given to the project of the international map by the assembly of an international committee in November, 1909. Sir Charles, now Lord, Hardinge presided at the opening session. There were delegates from Austria-Hungary, France, Germany, Great Britain, Canada and Australia, Italy, Russia, Spain, and the United States, and, as is known, the resolutions which were devised by the committee were agreed to unanimously. After the conclusion of the work of the committee the Government communicated the resolutions to all countries which had not been represented, and nearly all the replies which have been received are favourable. Maps in exact accordance with the resolutions are, it is understood, being produced by France, Hungary, Italy, Spain, the United States, and other countries, and so far as we are concerned, by the General Staff, the Ordnance Survey, and India. These maps will be shown at the International Geographical Congress which meets at Rome in October next.

I have now come to the end of this rapid sketch of the geographical work of the official world. It is work which, though often of an apparently humdrum character, outweighs in importance the sum-total of all which can be undertaken by private agency or by societies. But it is the very legitimate business of societies to criticize and encourage.

It is, in fact, not only our manifest duty to encourage the systematic mapping of the world on which we live, but we should do all we can to ensure the perfection and suitability for their special purposes of the maps themselves. In the surveying of the Earth's surface and its representation by means of maps we are treating of matters which are essentially and peculiarly our own. 
It would appear that another great function of geography, as represented by geographical societies and congresses, is to serve as a popularizing medium for such sciences as geodesy, geology, climatology, and anthropology, and also to serve as the means of bringing together the workers in these sciences. We may be told that so far as this Association is concerned the exact study of geodesy and meteorology is dealt with by Section A, geology by Section C, and anthropo$\operatorname{logy}$ by Section H, but there is, I believe, no other section which forms a more convenient general meeting-ground for all the workers in the various divisions of Earth-knowledge. We ourselves have our own special work, work which is shared by no others, the great task of mapping the world. This task is such a necessary one, and it is of such genuine value to so many studies, that by assisting in it we are really furthering the advancement of science, which is the object of this great Association.

\section{ZOOGEOGRAPHY.*}

WE have received the second issued volume of the Physical Atlas now being published by the Edinburgh Geographical Institute, the fifth in sequence of the seven that this great undertaking, which is issued under the special patronage of the Royal Geographical Society, will comprise. Volume 3, on Meteorology, has already appeared, and we may expect shortly-the sooner the more welcomethe remaining volumes in preparation. The present instalment is entitled Atlas of Zoogeography. Its authors are Dr. J. G. Bartholomew, Mr. Eagle Clarke, and Mr. Grimshaw. The former is responsible for the cartography, and the two latter conjointly for the zoological details on which the maps are based.

It goes without saying that the cartographical portion of the work-cvery map apart from its utility is a colour scheme delightful to the eye-is of the highest standard of the Institute whence it emanates, which Dr. Bartholomew and his forbears have made so famous. Only one misprint, so far as we have discovered, has escaped the vigilant eye of the "reader," namely Paprida on Plate xii. Map 4, for Pipridce, which is, however, correctly indexed. Charts are given of all the families of mammals, birds, reptiles, and amphibians, with several of their more important genera and species ; of most of the fish families, and of a selection of the families and genera of the Mollusca and Insecta. There are thirty-six plates, the majority of them containing six maps, so that there are nearly two hundred of the latter in all. The distributions-printed in distinctive colours-are confined to two or three families (or genera) only on each map, so as to obviate the risk of confusion from overcrowding. It may seem, perhaps, ungrateful and greedy after this liberal benefaction, in which over seven hundred families, genera, and species are illustrated, to express some regret that an additional chart or two could not have been spared for such chorologically important groups as the earth-worms, freshwater Crustacea, Peripatus, and the Arachnida.

The plates are prefaced by an excellent and concisely written Introduction in four parts, by the zoological authors. The first deals with the general principles of distribution and the conditions favouring and limiting dispersal; the

* Bartholomew's Physical Atlas, vol. 5. 'Atlas of Zoogeography.' A series of maps illustrating the distribution of over seven hundred families, genera and species of existing animals. Prepared by J. G. Bartholomew, LL.D., F.R.s.E.; W. Eagle Clarke, F.R.s.e., F.L.s. ; and Percy H. Grimshaw, F.R.s.t., F.L.s. Published at the Edinburgh Geographical Institute, 1911. 